\title{
The vapA co-expressed virulence plasmid gene $v c g B$ (orf10) of the intracellular actinomycete Rhodococcus equi
}

\begin{abstract}
Correspondence
Wim G. Meijer

wim.meijer@ucd.ie
\end{abstract}

Received 16 March 2011

Revised 3 May 2011

Accepted 9 May 2011

\author{
Raúl Miranda-CasoLuengo, ${ }^{1}$ Aleksandra A. Miranda-CasoLuengo, ${ }^{1}$ \\ Enda P. O'Connell, ${ }^{1} \dagger$ Ruth J. Fahey, ${ }^{1} \ddagger$ Clara A. Boland, ${ }^{1} \S$ \\ Jose A. Vázquez-Boland ${ }^{2,3}$ and Wim G. Meijer ${ }^{1}$
}
${ }^{1}$ UCD School of Biomolecular and Biomedical Science and UCD Conway Institute, University College Dublin, Dublin 4, Ireland
${ }^{2}$ Microbial Pathogenesis Unit, Centre for Infectious Diseases, Ashworth Laboratories, King's Buildings, University of Edinburgh, Edinburgh EH9 3JT, UK

${ }^{3}$ Grupo de Patogenómica Bacteriana, Facultad de Veterinaria e Instituto de Biología Molecular y Genómica, Universidad de León, 24071 León, Spain

\begin{abstract}
The virulence plasmid of the pathogenic actinomycete Rhodococcus equi is essential for proliferation of this pathogen in macrophages and the development of disease. The pathogenicity island of this plasmid encodes a family of virulence-associated proteins (Vap), one of which (VapA) is a virulence factor. This paper describes the $v c g A B$ operon (vapA co-expressed gene), located upstream of the vapA operon. Transcription of the $v c g A B$ operon gave rise to transcripts with a half-life similar to those determined for other virulence plasmid genes (1.8 $\mathrm{min}$ ).

Transcription started at a promoter similar to the vapA promoter, and proceeded through an inefficient terminator into the downstream $v c g C$ gene. $\ln$ addition, $v c g C$ is also transcribed from a promoter downstream of $v c g B$. The $v c g A B$ and $v a p A$ operons were coordinately regulated by temperature and $\mathrm{pH}$ in a synergistic manner. The latter parameter only affected transcription at higher growth temperatures, indicating that temperature is the dominant regulatory signal.

Transcription of the $v c g A B$ operon increased 10-fold during the late exponential and stationary growth phases. Transcription was also upregulated during the initial hours following phagocytosis by phagocytic cells. In contrast to $v c g A$ and $v c g C$, the $v c g B$ gene is conserved in the porcine VapB-encoding plasmid, as well as in pathogenic mycobacteria. The coordinated regulation of $v c g B$ and $\operatorname{vap} A$, transcription of $v c g B$ following phagocytosis and conservation of $v c g B$ in pathogenic mycobacteria indicate a role for $v c g B$ and the $v c g$ genes in the virulence of $R$. equi.
\end{abstract}

\section{INTRODUCTION}

Although Rhodococcus equi was originally identified as a major pathogen of foals, it sporadically infects other animals and is increasingly recognized as an oppor-

tPresent address: National Centre for Biomedical Engineering Science, National University of Ireland, Galway, Ireland.

łPresent address: Department of Microbiology and Immunology, Veterinary Medical Center, Cornell University, Ithaca, NY, USA.

§Present address: Forensic Science Laboratory, Department of Justice Equality and Law Reform, Garda Headquarters, Phoenix Park, Dublin 8, Ireland.

Abbreviations: $C_{T}$, cycle threshold; qPCR, quantitative PCR; RT-qPCR, reverse transcriptase quantitative $P C R$.

A supplementary figure, showing a $V_{c g B}$ multiple sequence alignment, is available with the online version of this paper. tunistic pathogen of predominantly, but not exclusively, immunocompromised humans (Meijer \& Prescott, 2004; Muscatello et al., 2007). R. equi belongs to a group of actinomycetes that is characterized by a hydrophobic cell envelope containing mycolic acids, which includes Mycobacterium, Corynebacterium and Nocardia species. The majority of $R$. equi infections are associated with pyogranulomatous cavitating pneumonia, although systemic manifestations also occur, including osteomyelitis and cerebral infections (Meijer \& Prescott, 2004; Muscatello et al., 2007). $R$. equi is a pathogen of alveolar macrophages that is able to prevent endosomal maturation and the accompanying acidification of the phagolysosome (Hondalus \& Mosser, 1994; Toyooka et al., 2005). Proliferation of the pathogen in the endosomal compartment eventually results in the necrotic death of the host cell (Fernandez-Mora et al., 2005; Lührmann et al., 2004). Genomic analysis suggests that 
evolution of virulence occurred through cooption of existing virulence genes and also by gene acquisition via lateral gene transfer (Letek et al., 2010).

All equine and the majority of porcine and human isolates harbour a large plasmid consisting of a highly conserved backbone required for replication and conjugation that is also present in a plasmid harboured by the non-pathogenic Rhodococcus erythropolis (Letek et al., 2008; Sekine et al., 2006; Takai et al., 2000). The equine and porcine plasmids differ in a variable region of lower $\mathrm{G}+\mathrm{C}$ content than the remainder of the plasmid that corresponds to a pathogenicity island. It encodes a family of virulence-associated proteins (Vap), including the virulence factor VapA in equine isolates and its $\mathrm{VapB}$ homologue in pig isolates (Byrne et al., 2001; Letek et al., 2008; Ocampo-Sosa et al., 2007; Takai et al., 2000). VapA has been shown to be essential, but not sufficient, for proliferation of $R$. equi in macrophages and development of disease (Giguère et al., 1999; Jain et al., 2003). The vapA gene is located in the four-cistronic vapAICD operon, which is transcribed from a single promoter that is induced during growth at high temperature and low-to-neutral $\mathrm{pH}$, conditions which resemble the host environment (Byrne et al., 2008; Russell et al., 2004). Interestingly, mRNA processing and the differential mRNA stability of the vapAICD transcript result in a greater abundance of the vapA transcript relative to that of the three downstream genes (Byrne et al., 2008). The activity of the vapA promoter $\left(\mathrm{P}_{\text {vapA }}\right)$ is dependent on the presence of the LysR-type transcriptional regulator VirR, which is encoded within the five-cistronic virR operon (virR-orf5-vapH-orf7-orf8; Fig. 1) located upstream of the vapAICD operon (Byrne et al., 2007; Russell et al., 2004). In addition, evidence to date indicates that a response regulator encoded by orf 8 is also required for expression of the vapAICD operon (Russell et al., 2004). The activity of the virR operon promoter $\left(\mathrm{P}_{\text {virR }}\right)$ is negatively autoregulated by VirR, resulting in low-level, constitutive transcription. A second promoter $\left(\mathrm{P}_{\text {orf }}\right)$, located within the virR gene (Fig. 1), becomes active during growth at high temperature and low $\mathrm{pH}$, resulting in increased transcription of the four genes located downstream of $v i r R$, including orf8 (Byrne et al., 2007).

Located in between the virR and vapA operons are three genes, $v c g A B C$ (orf9, orf10, orf11), encoding small proteins of unknown function (Fig. 1). Only one of these, $v c g B$, is conserved in the $v a p B$ plasmid; $v c g A$ is present as a pseudogene, and $v c g C$ is absent (Letek et al., 2008). A DNA microarray analysis has shown that $v c g B$ and the two non-conserved genes are transcribed following uptake of $R$. equi in macrophages, suggesting they may play a role in virulence (Ren \& Prescott, 2003). Here we show that the $v c g B$ gene belongs to a gene family conserved in pathogenic mycobacteria that infect phagocytic cells. Its induction upon phagocytosis, synergistic regulation by temperature and $\mathrm{pH}$, coordinated regulation with the vapA operon, and conservation in the vapB plasmid strongly suggest a role for $v c g B$ in pathogenesis.

\section{METHODS}

Bacterial strains and growth conditions. Bacterial strains and plasmids used in this study are listed in Table 1 . R. equi 103, its plasmid-cured derivative and E. coli $\mathrm{DH} 5 \alpha$ were grown in LuriaBertani (LB) medium (Sambrook \& Russell, 2001) or in minimal medium supplemented with $20 \mathrm{mM}$ lactate (LMM), as previously described (Kelly et al., 2002). R. equi was routinely grown at $37^{\circ} \mathrm{C}$, $\mathrm{pH} 5.5$ (vapA-inducing conditions), or at $30^{\circ} \mathrm{C}$ and $\mathrm{pH} 8.0$ (vapA non-inducing conditions). Where appropriate, ampicillin at $50 \mu \mathrm{g}$ $\mathrm{ml}^{-1}$, and apramycin at $30 \mu \mathrm{g} \mathrm{ml}^{-1}$ (E. coli) or $80 \mu \mathrm{g} \mathrm{ml}^{-1}$ (R. equi), were added. For solid media, agar was added to $1.5 \%(\mathrm{w} / \mathrm{v})$.

Plasmid construction. Promoter probes were constructed using pREV6, as described by Byrne et al. (2007). Briefly, serially shortened DNA fragments from the $5^{\prime}$ end were produced by PCR using a common reverse primer, VCGCREV, with 8C_2089F, VCG_771F or VCG_389F, and were ligated into the ClaI site of pREV6 to produce $\mathrm{pP} 1, \mathrm{pP} 2$ and $\mathrm{pP} 3$, respectively. Construct orientation was checked by digestion with appropriate restriction enzymes and confirmed by double-strand sequencing.

$\mathrm{p} V \mathrm{cg} \mathrm{ABC}$, containing the t-tag downstream of $v c g C$, was used for the generation of a deleted version to locate the t-tag within $v c g A$. For this, $1 \mu \mathrm{g} \mathrm{pVcgABC}$ was double-digested with ApaI and NdeI restriction enzymes (New England Biolabs). Non-compatible overhanging ends were repaired with the Klenow fragment of DNA polymerase I. Thirty femtomoles of repaired product was recircularized with T4 DNA ligase and transformed into E. coli DH5 $\alpha$. Deletions were checked by PCR using primers 8C_2089F and VCGCREV, by digestion with relevant restriction enzymes and sequencing. In this case, the t-tag was used as a reporter for the comparison of the expression levels of $v c g A$ and $v c g C$. Reverse transcriptase quantitative PCR (RT-qPCR) analysis was performed as above but using the specific primer $\mathrm{t}$-tag167R for the reverse-transcription step.

pUO9S was constructed by cloning an $872 \mathrm{bp}$ PCR product containing $\mathrm{P}_{v c g A}$, the $3^{\prime}$ end of orf 8 and the $5^{\prime}$ end of $v c g A$ into the EcoRV site of pBluescript KSII +.

RNA isolation. RNA was isolated from $R$. equi grown in vitro as described previously (Russell et al., 2004). R. equi RNA was isolated from macrophages following phagocytosis of the pathogen using a guanidine thiocyanate-based lysis buffer [ $4 \mathrm{M}$ guanidine thiocyanate, $0.5 \%(\mathrm{w} / \mathrm{v})$ sodium $N$-lauryl sarcosine, $25 \mathrm{mM}$ sodium citrate, $0.1 \mathrm{M} \beta$-mercaptoethanol] as described elsewhere (Butcher et al., 1998; Rohde et al., 2007). Samples were vortexed and passed through a needle to shear macrophage DNA and to reduce viscosity. Intracellular bacteria were recovered by centrifugation. Pelleted bacteria were lysed using TRIzol (Sigma), and physically disrupted with zirconia beads in a MagNA Lyser instrument (Roche). Total RNA was isolated by chloroform extraction, followed by DNA digestion with Turbo DNase (Ambion) and application to a Qiagen RNeasy column with a second, in-column, DNA digestion with the RNasefree Dnase, as previously described (Miranda-CasoLuengo et al., 2005).

Reverse transcription and PCR. Reverse-transcriptase reactions using hexameric random primers (Promega) were performed with $1 \mathrm{U}$ ImProm-II reverse transcriptase (Promega) following the manufacturer's recommendations with $100 \mathrm{ng}$ total RNA as template in a final volume of $20 \mu \mathrm{l}$. The resulting product was used in either an end point PCR or an RT-qPCR. For the former, $2 \mu \mathrm{l}$ of the reaction mixture was used as template for GoTaq Flexi DNA polymerase (Promega), as described by the manufacturer. For RTqPCR, the product was amplified using the QuantiTect SYBR Green real-time kit following the manufacturer's instructions (Qiagen). Reaction mixtures were subjected to 40 cycles of $95{ }^{\circ} \mathrm{C}$ for $15 \mathrm{~s}$, 

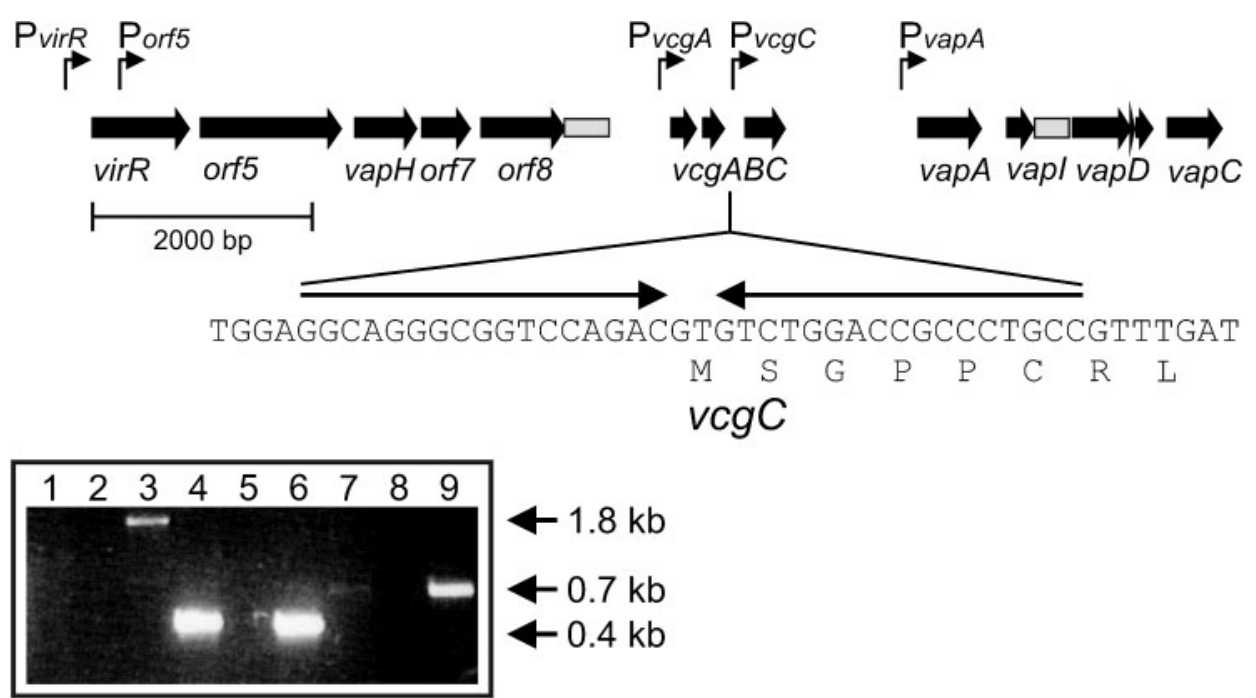

Fig. 1. Transcriptional organization of the $v c g A B C$ gene cluster and flanking virR (Byrne et al., 2007) and vapA (Byrne et al., 2008) operons of the VapA virulence plasmid of $R$. equi. Promoter location is shown by hooked arrows and by ' $P$ '. The grey boxes downstream of orf8 and vapl represent a vap pseudogene (Russell et al., 2004) and the frame-shifted 5' end of vapl (Polidori \& Haas, 2006), respectively. The nucleotide sequence of a 17 bp inverted repeat downstream of $v c g B$ and partially overlapping the $5^{\prime}$ end of $v c g C$ is delineated by arrows. The insert shows the results of the reverse transcriptase analysis of the $v c g A B$ operon using the oligonucleotide pairs 08F/09R (predicted size $1880 \mathrm{bp}$ ) complementary to orf8 and $v c g A$ (lanes 1-3), 09F/010R (predicted size $477 \mathrm{bp}$ ) complementary to $v c g A$ and $v c g B$ (lanes 4-6), and 010F/011R (predicted size $738 \mathrm{bp}$ ) complementary to $v c g B$ and $v c g C$ (lanes 7-9). Lanes 1, 4 and 7, $2 \mu$ lof the reverse transcriptase reaction (cDNA); lanes 2, 5 and 8 , reaction without reverse transcriptase; lanes 3, 6 and 9, reaction using genomic DNA as template.

$60{ }^{\circ} \mathrm{C}$ for $30 \mathrm{~s}$ and $72{ }^{\circ} \mathrm{C}$ for $30 \mathrm{~s}$ in a LightCycler (Roche) with temperature transition rates of $20{ }^{\circ} \mathrm{C} \mathrm{s}^{-1}$. Melting curve analysis was performed at $50-95{ }^{\circ} \mathrm{C}$ (temperature transition $0.2{ }^{\circ} \mathrm{C} \mathrm{s}^{-1}$ ), with continuous fluorescence detection following amplification. Cycle threshold $\left(C_{\mathrm{T}}\right)$ values were obtained and used to calculate the number of RNA copies per microgram of total RNA using a standard curve of known amounts of DNA target with $r^{2}$ coefficients greater than 0.997 in the range of $5 \times 10^{3}$ to $5 \times 10^{8}$ molecules per reaction. $16 \mathrm{~S}$ rRNA was used as a control to compare the amount of RNA in each reaction.
A relative approach was used for the quantification of intramacrophage $R$. equi transcript levels. Normalization of gene expression was performed by the $(1+\mathrm{E})^{-\Delta \mathrm{C}_{\mathrm{T}}}$ method (Pfaffl, 2004) using 16S rRNA as an internal control. Efficiencies $(E)$ of amplification were determined for each pair of primers by running standard curves with $r^{2}$ coefficients greater than 0.99 in the range of $10^{2}$ to $10^{5} R$. equi genomic equivalents using the formula $\mathrm{E}=\left(10^{\left(1 /-\mathrm{m}_{\mathrm{PCR}}\right)}-1\right)$, where $m_{\mathrm{PCR}}$ is the slope of the standard curve. $E$ values for $16 \mathrm{~S}$ rRNA, $v c g A$, $v c g B$ and $v c g C$ were $1.03,1.03,0.87$ and 0.93 , respectively. The data reported in this paper represent the results of three independent

Table 1. Bacterial strains and plasmids used in this study

\begin{tabular}{|c|c|c|}
\hline $\begin{array}{l}\text { Strain or } \\
\text { plasmid }\end{array}$ & Genotype or characteristics & Source or reference \\
\hline \multicolumn{3}{|l|}{ Strains } \\
\hline E. coli $\mathrm{DH} 5 \alpha$ & supE44 lacU169 ( $\phi 80$ lacZ M15) hsdR17 recA1 endA1 gyrA96 thi-1 relA1 & Bethesda Research Laboratories \\
\hline R. equi 103 & Virulent strain, $81 \mathrm{~kb}$ virulence plasmid & De La Peña-Moctezuma et al. (1996) \\
\hline \multicolumn{3}{|l|}{ Plasmids } \\
\hline pREV6 & Promoter probe vector containing a t-tag located within two transcriptional terminators & Byrne et al. (2007) \\
\hline pDrive & TA cloning vector & Qiagen \\
\hline pP1 & $\begin{array}{l}\text { pREV6 with a } 2089 \text { bp DNA fragment containing promoters } \mathrm{P}_{v c g A} \text { and } \mathrm{P}_{v c g C} \text {, 'orf8, } \\
v c g A, v c g B \text { and } v c g C\end{array}$ & This study \\
\hline pP2 & pREV6 with a 771 bp DNA fragment containing $\mathrm{P}_{v c g C},{ }^{\prime} v c g B$ and $v c g C$ & This study \\
\hline pP3 & pREV6 with a 389 bp DNA fragment containing ' $v c g C$ & This study \\
\hline $\mathrm{pVcgA}$ & pREV6 with an 893 bp DNA fragment containing $\mathrm{P}_{v c g A}$, 'orf8 and $v c g A^{\prime}$ & This study \\
\hline pUO9S & $\begin{array}{l}\text { pDrive with an } 872 \text { bp DNA fragment containing the upstream sequence and the } 5 \text { ' } \\
\text { end of } v c g A\end{array}$ & This study \\
\hline
\end{tabular}


experiments in which each sample was analysed in duplicate. The sequences of oligonucleotides used for RT-qPCR are listed in Table 2.

mRNA half-life determination. The rate of mRNA decay was determined as described previously (Byrne et al., 2008). Briefly, transcription was halted during mid-exponential growth by addition of rifampicin $\left(200 \mu \mathrm{g} \mathrm{ml}^{-1}\right)$. The half-life of specific transcripts was determined by RT-qPCR followed by linear regression.

Fluorescent primer extension and DNA sequencing. WellRED D4-labelled oligonucleotide D4-ORF9PEx (Table 2), complementary to sequences $20-39$ bp downstream of the initiation codon of $v \operatorname{cg} A$, was used in the primer extension reaction to find the transcriptional start site of the $v c g A B$ operon, as previously described (Byrne et al., 2007). Briefly, $2 \mu \mathrm{g}$ total RNA was reverse-transcribed using ImPromII reverse transcriptase (Promega), and the RNase-treated product was combined with DNA Size Standard kit 600 (Beckman Coulter) and analysed with a Beckman CEQ 8000 Genetic Analysis System following the manufacturer's directions (Beckman Coulter). In parallel, a dideoxy sequencing reaction with the ORF9PEx primer was carried out using NheI-digested pUO9S as template and the GenomeLab DTCS kit as directed by the manufacturer (Beckman Coulter). pUO9S harbours an 872 bp PCR fragment covering the intergenic region of orf8 and $v c g A$ obtained with $\mathrm{VP} 9445 \mathrm{~F}$ and ORF9PEx primers and cloned into the pDrive vector using the Qiagen PCR cloning kit as directed by the manufacturer (Qiagen). D4labelled primer extension products were added to the dideoxy sequencing products prior to analysis with the Beckman CEQ 8000 Genetic Analysis System to identify the transcriptional start site.

VapA quantification. $R$. equi was harvested by centrifugation $\left(10 \mathrm{~min}, 4000 \mathrm{~g}, 4{ }^{\circ} \mathrm{C}\right.$ ) and resuspended in $100 \mathrm{mM} \mathrm{Tris} / \mathrm{HCl}$ (pH 8.0) and $10 \mathrm{mM}$ EDTA ( $\mathrm{pH} 8.0$ ). Cells were lysed by three passages through a French press and cell debris was removed by centrifugation $\left(10 \mathrm{~min}, 14000 \mathrm{~g}, 4{ }^{\circ} \mathrm{C}\right)$. Soluble cell extracts were boiled for $10 \mathrm{~min}$ in SDS [62.5 mM Tris/HCl (pH 6.8), $10 \%(\mathrm{v} / \mathrm{v})$ glycerol, 2\% SDS, 5\% 2-mercaptoethanol, $0.02 \%$ bromophenol blue], and applied to a denaturing polyacrylamide gel. Proteins were subsequently transferred onto a PVDF membrane (Immobilon-P, Millipore) according to the manufacturer's instructions. Immunoblot analysis was performed with a chemiluminescent Western blot analysis system (Lumi-Light Western Blotting Substrate, Roche). Monoclonal antibody against VapA (Mab 10G5; provided by S. Takai, Kitasato University, Towada, Japan) was used for immunoblotting procedures. Protein was quantified using the Bio-Rad Multi-Imaging system and the Bio-Rad Quantity One software package.

Infection of J774A.1 cells. Bacteria grown in LMM were centrifuged $(10 \mathrm{~min}, 3220 \mathrm{~g}$ ) and washed twice with cation-free PBS (Sigma). Murine macrophage-like cells J774A.1 were seeded at $6 \times 10^{5}$ cells $\mathrm{ml}^{-1}$ in $6 \mathrm{~cm}$ tissue culture plates (Sarstedt) and cultured at $37{ }^{\circ} \mathrm{C}$ in $5 \% \mathrm{CO}_{2}$ overnight. Monolayers were washed once with pre-warmed phagocytosis buffer [0.1\% (w/v) gelatin, equal amounts of Medium 199 and Dulbecco's modified Eagle's medium (DMEM)] (Hondalus et al., 1993), and the medium was replaced with phagocytosis buffer containing $5 \%$ mouse serum (Sigma) as a source of complement. J774A.1 cells were infected with $R$. equi at an m.o.i. of 20. Infections were initiated by centrifugation $(160 \mathrm{~g}, 3 \mathrm{~min})$ of bacteria onto confluent monolayers to synchronize the internalization. Plates were incubated for $45 \mathrm{~min}$ at $37{ }^{\circ} \mathrm{C}$ in $5 \% \mathrm{CO}_{2}$. Monolayers were washed three times with warm phagocytosis buffer $\left(37^{\circ} \mathrm{C}\right)$ to remove unbound bacteria and incubated for a further $15 \mathrm{~min}$ to allow internalization of the attached bacteria. Monolayers were washed again with warm phagocytosis buffer. Phagocytosis buffer was subsequently replaced with DMEM supplemented with $10 \%(\mathrm{v} / \mathrm{v})$ fetal calf serum, $4 \mathrm{mM}$ L-glutamine, $1 \%$ non-essential amino acids and $10 \mu \mathrm{g}$ gentamicin $\mathrm{ml}^{-1}$ (this time point was denominated $t=0$ ). Infected monolayers were harvested at different time points between 2

Table 2. Oligonucleotides used in this study

\begin{tabular}{|c|c|c|c|}
\hline Oligonucleotide & Sequence $\left(5^{\prime}\right.$ to $\left.3^{\prime}\right)$ & Purpose & Reference or source \\
\hline 16SrRNAF200 & ACGAAGCGAGAGTGACGGTA & Quantification of $16 \mathrm{~S}$ rRNA gene & Miranda-CasoLuengo et al. (2005) \\
\hline 16SrRNAR200 & ACTCAAGTCTGCCCGTATCG & Quantification of $16 \mathrm{~S}$ rRNA gene & Miranda-CasoLuengo et al. (2005) \\
\hline $08 \mathrm{~F}$ & GAACAACTGGGAATGGTGGT & RT-PCR & \\
\hline 09F & GCTTGTGGGTTCATCTGGTT & RT-PCR/quantification of $v c g A$ & This study \\
\hline 09R & TACAACGCAACGGCGTAAAG & RT-PCR/quantification of $v c g A$ & This study \\
\hline $010 \mathrm{~F}$ & GAGCCGACGCATGAAAGTA & RT-PCR/quantification of $v c g B$ & This study \\
\hline 010R & CCGCTCAGCAGAATCTAGAAG & RT-PCR/quantification of $v c g B$ & This study \\
\hline $011 \mathrm{~F}$ & TTGAGGATGTCGTGTCTTGC & RT-PCR/quantification of $v c g C$ & This study \\
\hline $011 \mathrm{R}$ & GATGCGTATGCGTGGACA & RT-PCR/quantification of $v c g C$ & This study \\
\hline $012 \mathrm{~F}$ & CAGTACGACGTTCACGGAGA & Quantification of vapA & Byrne et al. (2008) \\
\hline $012 \mathrm{R}$ & CACGGCGTTGTACTGGAAC & Quantification of $v a p A$ & Byrne et al. (2008) \\
\hline VCGCREV $^{*}$ & GACTATCGATCAATCGCCGTCCCTCTACGAAG & Construction of $\mathrm{pP}$ plasmids & This study \\
\hline t-tag167R & ACGGTCATGAATCGTTCGTT & Quantification of t-tag & This study \\
\hline $\mathrm{t}-\operatorname{tag} 167 \mathrm{~F}$ & CACGGCAAGACCATCTACTTC & Quantification of t-tag & This study \\
\hline 8C_2089F* & TATAATCGATATTGGCAGGGCCACGGCATT & Construction of $\mathrm{pP} 1$ & This study \\
\hline VCG_771F* & TGACATCGATCCTCATGCTCACACCTCAGCCA & Construction of $\mathrm{pP} 2$ & This study \\
\hline VCG_389F* & GTACATCGATACCGCCCTGCCGTTTGATC & Construction of $\mathrm{pP} 3$ & This study \\
\hline ORF9PEx $\dagger$ & AACCAGATGAACCCACAAGC & $\begin{array}{l}\text { Primer extension of } v c g A \text {, and } \\
\text { construction of pUO9S }\end{array}$ & This study \\
\hline VP9445F & TGTATGCGTGTCGAATGCTC & Construction of pUO9S & This study \\
\hline
\end{tabular}

${ }^{\star}$ Underlined sequences show ClaI restriction sites for cloning into pREV6.

$\dagger$ This oligonucleotide was used unmodified and fluorescently labelled with WellRed D4 dye for sequencing and primer extension, respectively. 
and $48 \mathrm{~h}$. Medium was replaced after $24 \mathrm{~h}$ with fresh medium containing $10 \mu \mathrm{g}$ gentamicin $\mathrm{ml}^{-1}$.

Enumeration of intracellular $\boldsymbol{R}$. equi. The intracellular proliferation of $R$. equi was assessed by quantitative PCR (qPCR). Monolayers washed twice with PBS were scraped at indicated times post-infection $(t=0,2,24$ and $48 \mathrm{~h}$ ), spun down, and resuspended in $10 \mathrm{mM}$ Tris/ $\mathrm{HCl}, \mathrm{pH}$ 8.0. Harvested samples were heated at $99{ }^{\circ} \mathrm{C}$ for $10 \mathrm{~min}$, and then spun down briefly to pellet cellular debris. qPCR amplifying $16 \mathrm{~S}$ rRNA was performed as described above. $C_{\mathrm{T}}$ values were used to calculate the $R$. equi cell number using a standard curve of known amounts of bacteria with $r^{2}$ coefficients greater than 0.9952 in the range of $1 \times 10^{2}$ to $1 \times 10^{6}$ bacteria per reaction.

Phylogenetic analysis. An alignment of the $\mathrm{VcgB}$ (Orf10) proteins and their mycobacterial homologues (Supplementary Fig. S1) was constructed using CLUSTAL_X (Larkin et al., 2007), and subsequently used to infer phylogenetic relationships using the programs supplied in the PHYLIP v3.68 software suite (Felsenstein, 1989). A distance matrix was calculated with PROTDIS using the Jones-Taylor-Thornton model (Jones et al., 1992). An unrooted phylogenetic tree was subsequently constructed via neighbour joining as implemented in the NEIGHBOR program.

RNA structure analyses. RNA structure and minimum free energy of prediction were done using the RNAfold of the Vienna RNA Server (http://rna.tbi.univie.ac.at/).

Statistical analyses. Statistical analyses were performed by Student's $t$ test for paired values. Differences were considered significant at $P<0.05$.

Gene nomenclature. The vapB-containing plasmid pVAPB1539 (accession no. AM947676) was recently annotated and the vapA plasmid pVAPA1037 (accession no. AM947677) was reannotated (Letek et al., 2008). The orf9 and orf11 genes of the latter plasmid were denoted pVAPA_0560 and pVAP_0580. The orf10 genes on the two plasmids were denoted pVAPB_0570 and pVAPA_0570, respectively. Since the orf9, 10 and 11 genes are regulated in a manner similar to the virulence gene $v a p A$, we propose to rename these genes to $v c g A$, $v c g B$ and $v c g C$, respectively ( $v a p A$ co-expressed gene).

\section{RESULTS}

\section{$v c g B$ is conserved in pathogenic Mycobacterium species}

A hallmark of the pathogenicity island of the $R$. equi virulence plasmid is the large proportion of genes that are unique to this pathogen, including the $v c g A$ and $v c g C$ genes. However, comparison by BLASTP and PSI-BLAST of $\mathrm{VcgB}$ with protein sequences deposited in GenBank revealed extensive similarities to a family of small mycobacterial proteins (Supplementary Fig. S1). In addition to these, $\mathrm{V} c g \mathrm{~B}$ homologues are also present, but not annotated, in the genomes of Mycobacterium tuberculosis H37Rv, Mycobacterium bovis BCG and Mycobacterium abscessus. The last species contains two $v c g B$ homologues, which are separated by $3 \mathrm{~kb}$. Interestingly, $v c g B$ homologues were not found in species other than in the genus Mycobacterium, and, with the exception of Mycobacterium smegmatis, all are pathogenic Mycobacterium species.
A phylogenetic analysis showed that the $\mathrm{VcgB}$ homologues grouped into two clusters (Fig. 2). Cluster 1 contained the Mycobacterium avium, M. avium subsp. paratuberculosis, Mycobacterium intracellulare, Mycobacterium ulcerans, Mycobacterium marinum, Mycobacterium kansasii and $M$. tuberculosis proteins, whereas the R. equi proteins grouped with those of M. smegmatis and M. abscessus. Cluster 1 represents slow-growing mycobacterial species, whereas the species present in the second cluster are fast-growing. The topology of the $\mathrm{VcgB}$ phylogenetic tree closely matches that of the 16S rRNA genes of these species (Devulder et al., 2005).

\section{The vcgAB genes form an operon}

The conservation of the $v c g B$ gene in pathogenicity islands of $R$. equi strains with different host specificities as well as in pathogenic mycobacteria suggests that this gene may play a role in the interaction with the host. The regulation and transcriptional organization of this gene was therefore analysed in greater detail. The $v c g$ gene cluster is located between the virR and vapA operons (Fig. 1). The close proximity of $v c g A$ to $v c g B(68 \mathrm{bp}$ ) suggests that they may be cotranscribed. In contrast, $v c g B$ is separated by $203 \mathrm{bp}$ from $v c g C$. This relatively large intergenic region between $v c g B$ and $v c g C$ contains a $17 \mathrm{bp}$ inverted repeat that may form a stable RNA structure with a free energy of $-39 \mathrm{kcal}$ $\mathrm{mol}^{-1}\left(-163 \mathrm{~kJ} \mathrm{~mol}^{-1}\right)$, which masks the initiation codon and ribosome-binding site of $v c g C$ (Fig. 1). This RNA structure is followed by three uridines, thus resembling an intrinsic terminator (Platt, 1986). To investigate the transcriptional organization of these genes, mRNA was isolated and reverse-transcribed from $R$. equi grown under vapA-inducing conditions. The resulting cDNA was amplified by PCR using oligonucleotide primers (Table 2) complementary to sequences in adjacent genes (Fig. 1). Strong amplification was observed when the $v c g A-v c g B$ pairs were used, whereas only a weak signal was detected when the $v c g B-v c g C$ primer pair was deployed. These data demonstrate that the $v c g A B$ genes form an operon, with probable read-through into $v c g C$. An amplicon was not observed when oligonucleotides were used that were complementary to orf8, the last gene of the virR operon, and $v c g A$, showing that the $v c g$ gene cluster is not dependent on promoters in the virR operon (Fig. 1).

\section{The vcgABC cluster contains an internal promoter}

The RT-PCR experiments clearly showed that $v c g A$ and $v c g B$ are cotranscribed, whereas the weak signal obtained following RT-PCR using the $v c g B-v c g C$ primer pair suggested that read-through from $v c g B$ into the downstream $v c g C$ gene might occur. To examine whether this was the case, the ability of sequences upstream of $v c g C$ to drive transcription of $v \operatorname{cgC}$ was examined using the promoter probe vector pREV6 (Fig. 3a). This vector contains a small DNA fragment ( $\mathrm{t}$-tag) located in between two transcriptional terminators that is absent in the $R$. equi 


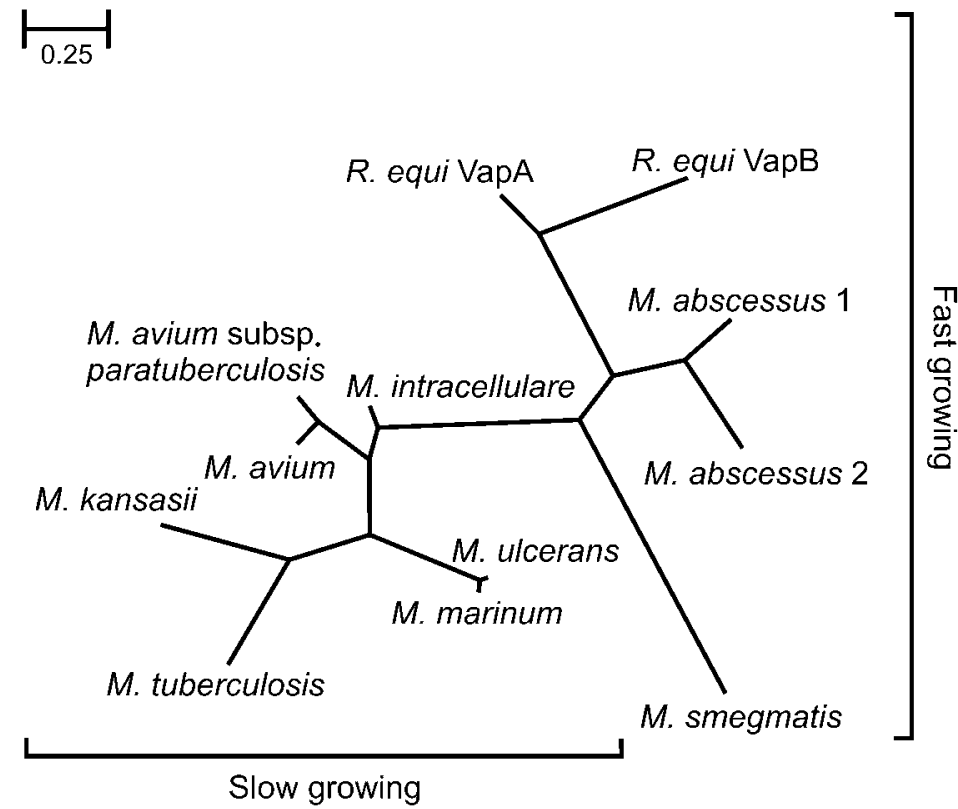

Fig. 2. Phylogenetic relationships of $V_{c g B}$ (pVAPA_0570 and pVAPB_0570) of the VapA and VapB virulence plasmids (Letek et al., 2008; Takai et al., 2000), respectively, and homologous proteins in Mycobacterium species. The tree is based on a distance analysis using protein sequences from $M$. avium MAV5198 (NC_008595), M. avium subsp. paratuberculosis MAP3516 (Li et al., 2005), M. intracellulare MintA_22949 (ZP_05227808), M. kansasii

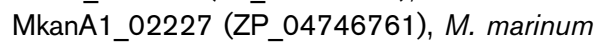
MMAR0314 (Stinear et al., 2008), M. smegmatis MSMEG5646 (NC_008596), M. tuberculosis MT0124 (Fleischmann et al., 2002) and M. ulcerans MUL4808 (Stinear et al., 2007). The proteins from $M$. abscessus are not annotated; protein sequences were derived from nucleotides 2763298-2763170 (in between MAB2716c and MAB2715c) and 2766 687-2 766553 (in between MAB2718c and MAB2717c) of the M. abscessus genome (NC_010397). The M. tuberculosis H37Rv protein is not annotated; the protein sequence is derived from nucleotides 139 965-140141 (in between Rv0115 and Rv0116c) of the $M$. tuberculosis H37Rv genome (Cole et al., 1998). genome and virulence plasmid (Byrne et al., 2007). Introduction of the complete $v c g A B C$ cluster and the orf8- $v c g A$ intergenic region in pREV6 resulted in transcription of the t-tag, demonstrating the presence of an active promoter. Deletion of the orf $8-v c g A$ intergenic region, as well as $v c g A$ and the $5^{\prime}$ end of $v c g B$, reduced transcription twofold. Further deletion of $v c g B$ and the $5^{\prime}$ end of $v c g C$ abolished transcription of the t-tag completely (Fig. 3b). These data show that read-through from a promoter $\left(\mathrm{P}_{v c g A}\right)$ upstream of $v c g A$ into $v c g C$ does occur, despite the presence of a putative terminator, since deletion of this promoter reduced transcription of the t-tag by $50 \%$. The fact that transcription was not abolished completely demonstrates the presence of a second promoter $\left(\mathrm{P}_{v c g C}\right)$ that drives transcription of the $v c g C$ gene.

\section{Transcriptional termination occurs between $\operatorname{vcg} A B$ and $\operatorname{vcg} C$}

The $v c g A B-v c g C$ intergenic region contains a putative terminator structure, although read-through past this putative terminator occurs. To examine the relative transcription levels of $v c g A B$ and $v c g C$ and to determine whether there is termination in between the former and latter, the transcript levels of $v c g A$ relative to $v c g C$ were determined. Using primers complementary to $v c g A$ and $v c g C$, a 20 -fold difference in transcript level was detected (Fig. 3c). To rule out that this difference was due to a difference in reverse transcription efficiency, the t-tag in pREV6 was placed either behind the $\mathrm{P}_{v c g A}$ promoter $(\mathrm{pVcgA})$ or behind both $\mathrm{P}_{v c g A}$ and $\mathrm{P}_{v c g C}(\mathrm{pP} 1)$. In this case, the effects of differential reverse transcription are negated since the same template for reverse transcription is used. As before, a 20-fold difference in transcription was observed when comparing the former with the latter (Fig. $3 \mathrm{c})$. These data thus demonstrate that the $v c g A B$ transcripts are at least 20-fold more abundant than the $v c g C$ transcript. In addition, they show that the putative terminator downstream of $v c g A B$ is approximately $90 \%$ effective.

\section{Growth phase-dependent transcription of the vcg genes}

$R$. equi was grown under vapA-inducing conditions, and $v c g A B C$ transcript levels were determined during the exponential (0-12 h) and stationary (12-48 h) growth phases (Fig. 4). The transcript levels of $v c g A B$ increased approximately 10-fold during the late exponentional and stationary growth phases compared with early exponential growth. Similarly, $v c g C$ levels increased approximately 10fold during the late exponentional phase, but subsequently fell to levels similar to those at the start of the experiment. The half-lives of the $v c g A(1.7 \pm 0.2 \mathrm{~min}), v c g B$ $(1.8 \pm 0.2 \mathrm{~min})$ and $v c g C(1.7 \pm 0.4 \mathrm{~min})$ transcripts were similar to those reported for the genes of the virR operon (1.8 min) (Byrne et al., 2007) and the vapICD genes of the vapA operon (Byrne et al., 2008). In contrast, the vapA transcript is more stable, with a reported half-life of $7.5 \mathrm{~min}$ (Byrne et al., 2008). The short half-lives of the $v c g$ transcripts show that the 10-fold increase in $v c g A B$ and $v c g C$ transcript levels was not due to accumulation of a relatively stable transcript during growth, but instead was 
(a)
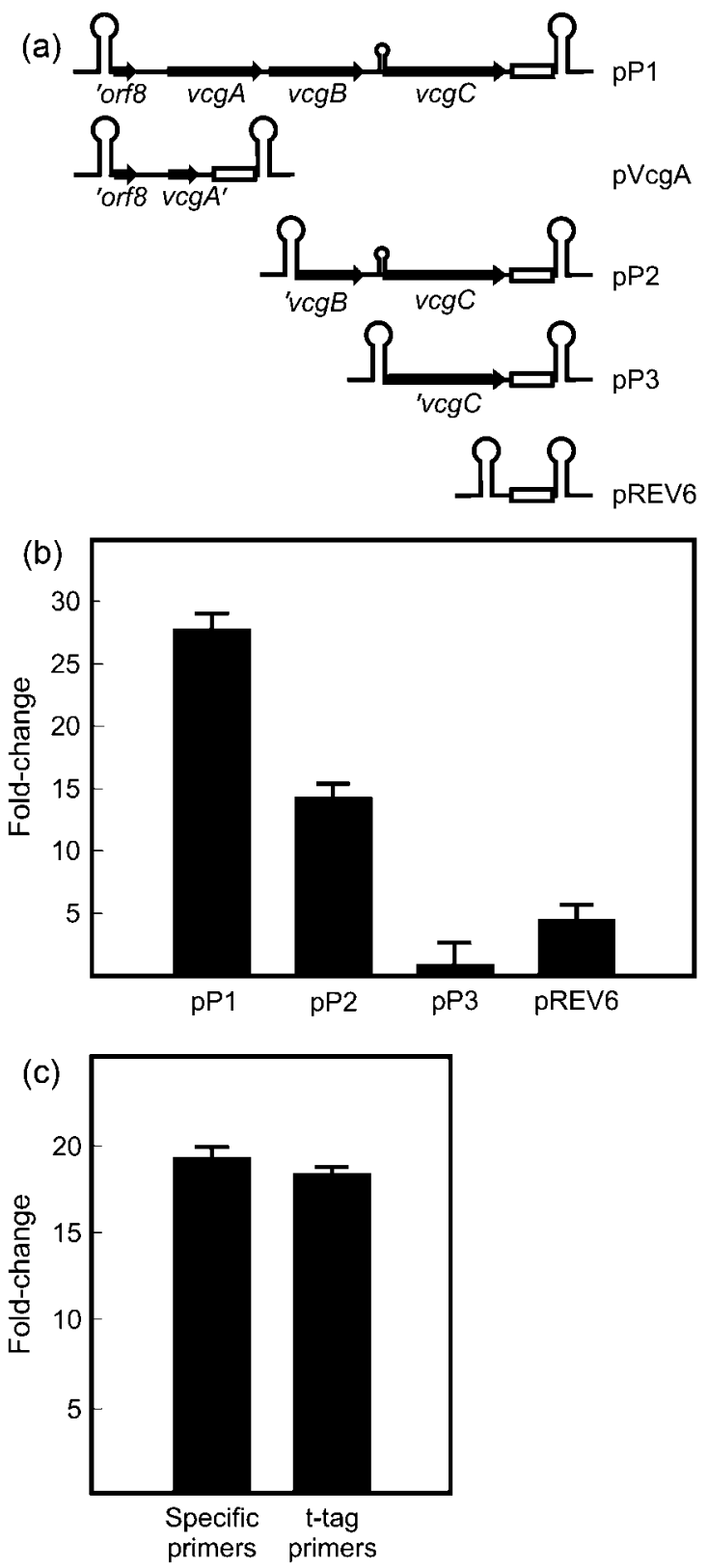

Fig. 3. Determination of the $\mathrm{P}_{v c g A}$ and $\mathrm{P}_{v c g C}$ promoter activities by RT-qPCR. (a) Schematic representation of inserts in the promoter probe vector pREV6. Hairpin structures represent transcriptional terminators: large hairpin structures are the transcriptional terminators of pREV6; the small hairpin structure indicates the position of the putative terminator downstream of $v c g B$. Genes and their direction of transcription are indicated by black arrows. The white box represents the transcription tag ( $t$-tag). The transcription level of the t-tag was measured by RT-qPCR. (b) Relative mRNA transcript levels of the t-tag in $R$. equi harbouring plasmids pP1, pP2, pP3 and pREV6. Fold changes were obtained by calibrating against the promoterless probe (pP3). (c) mRNA transcript levels of $v c g A$ relative to $v c g C$. Transcript levels were determined using primers specific to $v c g A$ and $v c g C$ and RNA isolated from $R$. equi 103 , or using primers specific for the t-tag and RNA isolated from $R$. equi harbouring either $\mathrm{pP} 1$ or $\mathrm{pV} \operatorname{cgA}$. $t$-tag transcription of $\mathrm{pP} 1$ depends on the activities of the $\mathrm{P}_{v c g A}$ and $\mathrm{P}_{v c g C}$ promoters as well as the efficiency of the putative terminator downstream of $v c g B$. t-tag transcription of $\mathrm{pVcgA}$ depends on the activity of the $\mathrm{P}_{v c g A}$ promoter.

due to an increased transcription of the $v c g$ operon during the mid- to late-exponential growth phase that continued into the stationary phase for the $v c g A B$ genes, but not for $v c g C$ (Fig. 4).

\section{Co-regulation of the vcgAB and vapA operons: synergistic effect of high temperature and low pH}

Transcription of the vapA operon, which is located downstream of the $v c g$ genes, is induced during growth at low $\mathrm{pH}$ and high temperature, resembling the conditions encountered by $R$. equi in the host (Takai et al., 1996). To compare the regulation of the $v c g A B$ and $v a p A$ operons, their transcription was determined following growth under vapA-inducing $\left(\mathrm{pH} 5.5,37^{\circ} \mathrm{C}\right)$ and non-inducing growth conditions $\left(\mathrm{pH} 8.0,30{ }^{\circ} \mathrm{C}\right)$ by determining the mRNA levels of $v c g B$ and $v a p A$ (Fig. 5). The $v c g B$ and $v a p A$ mRNA levels under the former growth conditions were, respectively, 20- and 100-fold higher compared with the latter, demonstrating that transcription of the $v c g$ operon is also induced by low $\mathrm{pH}$ and high growth temperature (Fig. 5a). To determine the relative contributions of each environmental parameter, temperature and $\mathrm{pH}$ were varied individually. Changing the $\mathrm{pH}$ of the medium from $\mathrm{pH} 8.0$ to $\mathrm{pH} 5.5$ while keeping the temperature at $30{ }^{\circ} \mathrm{C}$ resulted in relatively little change in the transcription level of either operon compared with non-inducing growth conditions. In contrast, an increase in growth temperature from 30 to $37{ }^{\circ} \mathrm{C}$, while keeping the $\mathrm{pH}$ at 8 , had a more significant, yet modest, effect (respectively, eight- and 32 -fold increases in $v c g B$ and $v a p A$ mRNA levels). The data thus show that $\mathrm{pH}$ only significantly affected transcription of the $v c g$ and vapA operons at $37^{\circ} \mathrm{C}$ but not at $30^{\circ} \mathrm{C}$, whereas growth temperature affected transcription at both low and high $\mathrm{pH}$. However, it is clear that a simultaneous reduction in $\mathrm{pH}$ and increase in temperature had a synergistic effect on the transcription of the $v c g A B$ and $v a p A$ operons.

To further validate these results, the expression levels of VapA protein were determined using monoclonal antibodies directed against VapA (Fig. 5b). The VapA expression pattern was the same as the vapA transcription pattern. As was observed for the vapA transcript levels, VapA protein levels increased by approximately 100 -fold when comparing non-inducing with inducing growth conditions. Furthermore, a decrease in $\mathrm{pH}$ and increase in temperature of the growth medium had a synergistic effect on the VapA protein expression levels, while $\mathrm{pH}$ did not significantly affect expression at $30{ }^{\circ} \mathrm{C}$. 


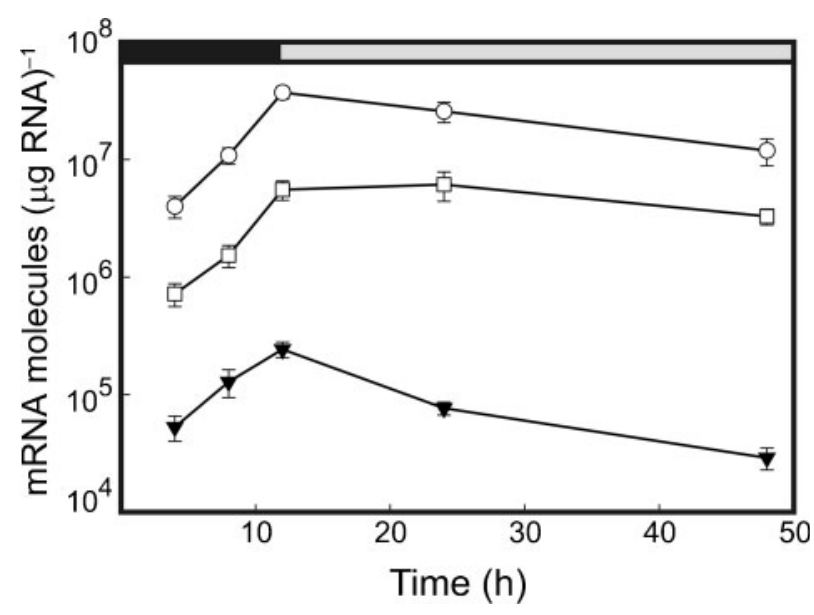

Fig. 4. Absolute quantification of the $\operatorname{vcg} A(\bigcirc), v c g B(\square)$ and $v c g C$ $(\boldsymbol{\nabla})$ transcripts of the virulence plasmid of $R$. equi during growth in LB medium at $\mathrm{pH} 5.5,37{ }^{\circ} \mathrm{C}$. Shown are the means $\pm \mathrm{SD}$ (error bars) of three independent experiments in which each sample was analysed in duplicate. The black and grey bars represent, respectively, the exponential and stationary growth phases of $R$. equi.

\section{The $v c g A B$ operon and $v c g C$ are transcribed in macrophages}

A DNA microarray study has shown that the genes of the pathogenicity island, including the $v c g$ genes, are transcribed in macrophages, although these microarray data have not been validated by other techniques (Ren \& Prescott, 2003). To date, no temporal transcription profile of these genes, or of any other genes, following uptake of $R$. equi by macrophages, has been determined. To examine the regulation of the $v c g$ genes in vivo, macrophages were infected with virulent and avirulent $R$. equi pregrown on minimal medium supplemented with lactate at $37^{\circ} \mathrm{C}, \mathrm{pH}$. As expected, virulent $R$. equi proliferated within macrophages, whereas the avirulent plasmid-free strain did not (Fig. 6a). RNA was extracted over a $48 \mathrm{~h}$ period, and the relative transcription levels of $v c g A, \quad v c g B$ and $v c g C$ were determined (Fig. 6b). Transcript levels increased two- to fivefold in the initial $8 \mathrm{~h}$ following infection and declined to the initial levels in the subsequent $40 \mathrm{~h}$.

\section{The promoter of the vcgAB operon is similar to the vapA and virR operon promoters}

Since the $v c g A B$ operon is regulated in a similar manner to the vapA operon, it seems likely that the promoters of the two are similar. To compare the $v c g A B$ promoter with previously identified $R$. equi promoters (Byrne et al., 2007; Russell et al., 2004), the transcriptional start site of the $v c g A B$ operon was determined by primer extension using the fluorescently labelled oligonucleotide D4-ORF9PEx, which was hybridized to mRNA isolated from $R$. equi grown under vapA-inducing conditions. Reverse transcription resulted in a major primer extension product with an estimated size of $331 \mathrm{bp}$ (Fig. 7a). The transcriptional start site inferred from the major extension product mapped to a cytidine $292 \mathrm{bp}$ upstream of the $v c g A$ start codon $\left(\mathrm{C}_{292}\right)$. In addition, a shorter, minor extension product was observed with an estimated size of $257 \mathrm{bp}$, which
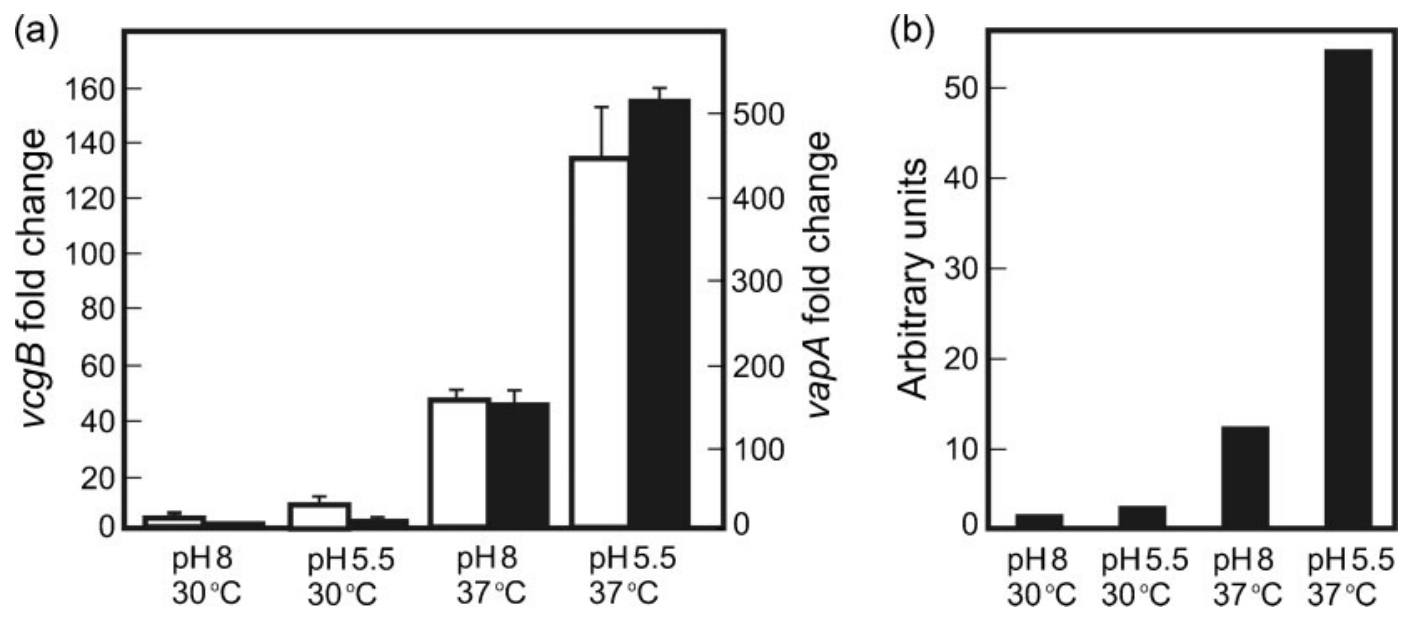

Fig. 5. Expression of $v c g B$ and $v a p A$ during the late exponential growth phase of $R$. equi on LB medium at $\mathrm{pH} 5.5$ or 8.0 and at 30 or $37^{\circ} \mathrm{C}$. Transcript levels were normalized to levels of $16 \mathrm{~S}$ rRNA and fold changes obtained against the expression levels under non-inducing conditions of growth ( $\mathrm{pH} 8.0$ and $30^{\circ} \mathrm{C}$ ). (a) Fold changes for $v c g B$ (white bars) and vapA (black bars). Transcript levels were normalized to levels of $16 \mathrm{~S}$ rRNA and fold changes obtained against the transcription levels under noninducing conditions of growth $\left(\mathrm{pH} 8.0\right.$ and $30^{\circ} \mathrm{C}$ ). Shown are the means $\pm \mathrm{SD}$ (error bars) of three independent experiments in which each sample was analysed in duplicate. (b) Expression levels of VapA protein following Western blotting using $\mathrm{mAb}$ $10 \mathrm{G} 5$ monoclonal antibodies. Equal amounts of protein were added to each lane. 


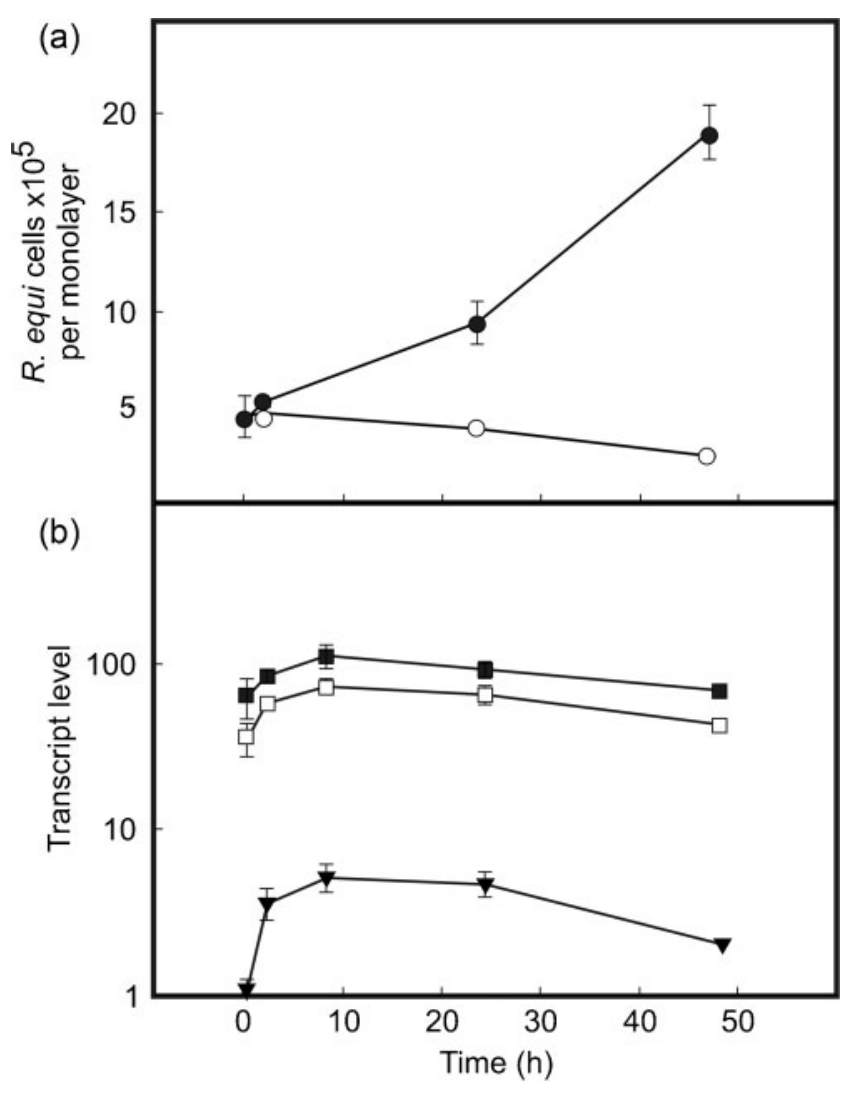

Fig. 6. Transcriptional profile of the $v c g$ gene cluster of the $R$. equi virulence plasmid following infection of the murine macrophagelike cell line J774A.1. Monolayers were infected with $R$. equi. Following a 45 min incubation to allow phagocytosis, monolayers were washed and treated with gentamicin to kill remaining extracellular bacteria $(t=0)$. Intracellular bacteria were enumerated by $\mathrm{qPCR}$ using the $16 \mathrm{~S}$ rRNA gene as template. (a) Intracellular proliferation of isogenic strains $R$. equi $103^{+}(0)$ and $R$. equi $103^{-}(\bigcirc)$. (b) Transcription levels of $\operatorname{ccg} A(\boldsymbol{\square}), \operatorname{vcg} B(\square)$ and $v c g C(\nabla)$ relative to the levels of $10^{6}$ molecules of $16 S$ rRNA. Values are shown as means \pm SD (error bars).

corresponded to a thymidine $219 \mathrm{bp}\left(\mathrm{T}_{219}\right)$ upstream of the $v c g A$ initiation codon (Fig. $7 \mathrm{~b}, \mathrm{c}$ ).

The -10 region upstream of $\mathrm{C}_{292}$ shares significant sequence similarity (Fig. $7 \mathrm{~d}$ ) with the promoter recognized by the principal sigma factor $\sigma^{\text {hrdB }}$ of Streptomyces coelicolor (Buttner et al., 1990; Kang et al., 1997). In addition, this region is similar to those of the previously identified $\mathrm{P}_{\text {virR }}$ and $\mathrm{P}_{\text {vapA }}$ promoters (Fig. 2) of the virR and vapA operons (Byrne et al., 2007; Russell et al., 2004). As was observed previously for the $\mathrm{P}_{\text {virR }}$ and $\mathrm{P}_{\text {vapA }}$ promoters, the -35 region upstream of $\mathrm{C}_{292}$ does not share significant similarity with that of the $\sigma^{h r d B}$ promoter. However, the -35 region of the vapA promoter and that of $\mathrm{C}_{292}$ are $56 \%$ identical, with three out of the four mismatches being transitions ( $89 \%$ similarity). In contrast, the region upstream of the minor extension product $\left(\mathrm{T}_{219}\right)$ does not share any similarities with previously identified $R$. equi promoters.

\section{DISCUSSION}

The $v c g A B$ operon is, after the virR and $v a p A$ operons, the third operon of the pathogenicity island to be described in detail (Byrne et al., 2007, 2008). Transcription of this operon terminates in an inefficient terminator downstream of $v c g B$, allowing some read-through from $v c g A B$ into the downstream $v c g C$ gene, which also has its own promoter. The RNA structure forming the $v c g A B$ terminator obscures both the $v c g C$ start codon and ribosome-binding site. This, together with the 20-fold lower $v c g C$ mRNA levels compared with $v c g A B$, suggests that $v c g C$ is very poorly expressed.

The transcriptional regulation of the $v c g A B$ operon was identical to that of the vapA operon. Although both temperature and $\mathrm{pH}$ control their transcription, the latter only had a significant effect at high temperatures. In contrast, a temperature increase induced transcription of both operons, regardless of $\mathrm{pH}$. Temperature therefore seems to be the primary environmental parameter that controls transcription of $v c g A B$ and $v a p A$, and, based on the VapA protein profiles, expression of the pathogenicity island genes. The role of temperature as the primary determinant to control virulence gene expression is common to many pathogens. Although the mechanisms to detect temperature are diverse, they often rely on detection of perturbation of the conformation of biomolecules such as RNA or lipids (Klinkert \& Narberhaus, 2009). The mechanism used by $R$. equi to control temperature-dependent virulence gene expression remains unknown. Interestingly, the effect of $\mathrm{pH}$ and temperature on transcription of the vapA and $v c g A B$ operons is not independent, but is clearly synergistic. This strongly suggests a common, as-yet-unidentified, denominator in the transduction of these unrelated signals to the transcriptional apparatus.

The transcript levels of the $v c g A B$ operon increased 10-fold at the end of the growth phase and remained high throughout the stationary phase. This suggests that the growth phase may be an important trigger for virulence gene expression, as has been observed in other pathogens, including Vibrio cholerae, Legionella pneumophila and Yersinia enterolitica (Hovel-Miner et al., 2009; Iriarte et al., 1995; Nielsen et al., 2006). R. equi grows rapidly in minimal media supplemented with, for example, volatile fatty acids, or in manure-enriched soils (Hughes \& Sulaiman, 1987; Kelly et al., 2002), whereas in macrophages, growth is relatively slow, which may be due to a restriction of nutrients such as iron (von Bargen et al., 2011). Furthermore, populations of slow-growing or stationary phase bacteria are more vulnerable to being wiped out by phagocytic cells or predatory protozoa than fast-growing bacterial populations. Increased transcription 

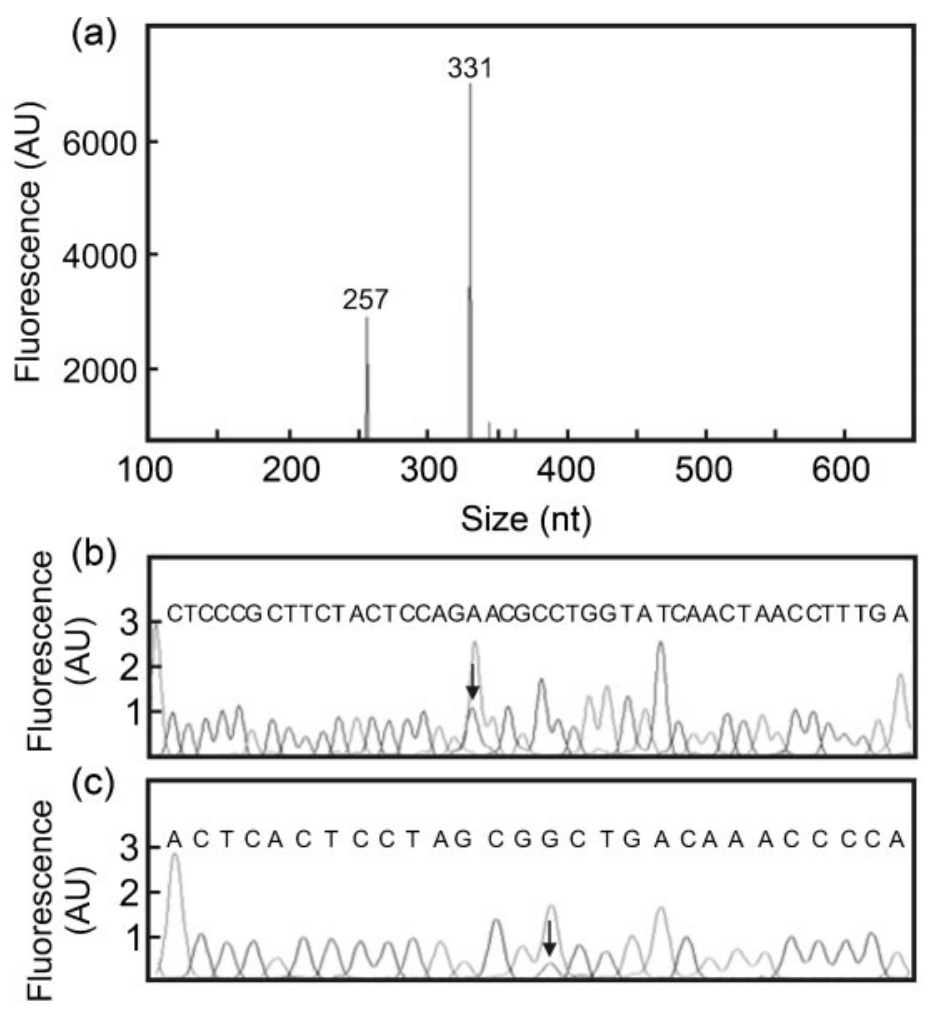

(d)

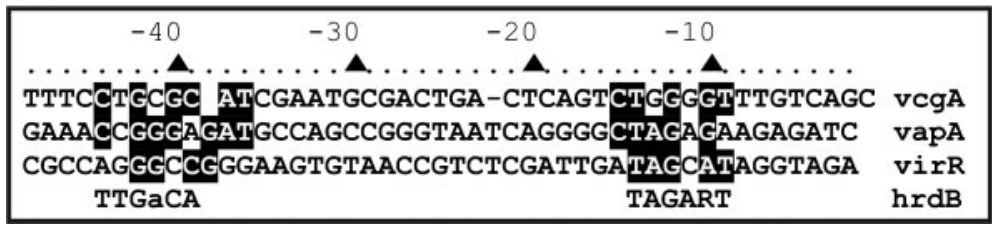

Fig. 7. Determination of the transcriptional start site of the $v c g$ operon of $R$. equi. Fluorescent primer extension was carried out with the D4-labelled primer and $2 \mu \mathrm{g}$ total cellular RNA extracted from $R$. equi grown under inducing conditions $\left(37^{\circ} \mathrm{C}\right.$ and $\mathrm{pH}$ 5.5). (a) Fragment length analysis of the D4-labelled primer extension product combined with DNA size standards. (b, c) Comigration of extension products with a dideoxy sequencing reaction; arrows indicate the complementary base of the $257 \mathrm{bp}$ (b) and $331 \mathrm{bp}$ (c) extension products. (d) Alignment of the promoters of the $\operatorname{vcg} A B$ operon, the vapA operon (Russell et al., 2004) and the virR operon (Byrne et al., 2007). The consensus sequence of the $\sigma^{\text {hrdB }}$-dependent $S$. coelicolor promoter (Buttner et al., 1990; Kang et al., 1997) is shown for comparison. Conserved nucleotides in the -10 and -35 regions are shown as white letters on a black background. of virulence genes during periods of slow or impaired growth may therefore be an adaptation to survive phagocytosis.

The similarity in transcriptional regulation of the vapA and $v c g A B$ operons is borne out in the similarity of the $\mathrm{P}_{v a p A}$ and $\mathrm{P}_{v c g A}$ promoter sequences, which resemble promoters dependent on the principal sigma factor $\mathrm{HrdB}$ of $S$. coelicolor (Buttner et al., 1990; Kang et al., 1997). The promoter of the virR operon is also similar to these sequences, albeit to a lesser extent (Byrne et al., 2007; Russell et al., 2004). This suggests that these three R. equi promoters are dependent on the principal sigma factor of $R$. equi. Interestingly, the internal $\mathrm{P}_{\text {orf } 5}$ promoter located within the virR operon (Fig. 2) is completely different, suggesting the involvement of an alternative sigma factor (Byrne et al., 2007).

The pathogenicity islands of the equine vapA and porcine $v a p B$ plasmids have undergone extensive rearrangements. These are probably associated with the host tropism of strains harbouring the plasmids following acquisition of the pathogenicity island by an ancestral rhodococcal plasmid (Letek et al., 2008). The $v c g B$ gene, located downstream of the virR operon, is conserved in both the vapA plasmid and the $v a p B$ plasmid (Letek et al., 2008). Unlike $v c g A, v c g C$ and the vap genes, $v c g B$ has homologues in other bacterial species, which, with the exception of M. smegmatis, are all pathogenic mycobacteria that infect phagocytic cells. A recent analysis of the genome of $M$. abscessus, a fast-growing pathogenic species, revealed that in addition to the presence of mycobacterial virulence genes, the genome has acquired genes associated with pathogenicity from non-mycobacterial species, most notably from other actinobacteria, including Rhodococcus sp. (Ripoll et al., 2009). The presence of nearidentical plasmids in M. marinum and M. abscessus indicates that lateral gene transfer between fast- and slow-growing mycobacteria may occur (Ripoll et al., 2009). However, the phylogeny of the mycobacterial $v c g B$ genes resembles that of the 16S rRNA gene (Devulder et al., 2005), indicating a vertical transmission of $v c g B$ from a common mycobacterial progenitor species. In contrast, the rhodococcal $v c g B$ genes are within a pathogenicity island that is located on a conjugative plasmid. As is the case for the pathogenicity island itself, the rhodococcal $v c g B$ genes were most likely acquired via a lateral gene transfer event (Letek et al., 2008, 2010; Takai et al., 2000). 
With the exception of $M$. smegmatis, $v c g B$ has only been identified in mycobacterial species that infect phagocytic cells of a wide diversity of hosts, ranging from fish to mammals. The $v c g B$ genes in these species survived reductive evolution of the genome that, for example, drove the emergence of M. ulcerans from M. marinum (Demangel et al., 2009). The R. equi genome appears to be genetically stable, and not subject to extensive rearrangement or reductive evolution (Letek et al., 2010). In contrast, the $R$. equi pathogenicity island has been subjected to extensive recent genetic rearrangements and gene corruption; for example, seven of the 23 pseudogenes in $R$. equi are located in the pathogenicity island, which represents only $0.5 \%$ of the total genome (Letek et al., 2008, 2010). While $v c g B$ is conserved in both the vapA plasmid and the vapB plasmid, the flanking $v c g A$ and $v c g C$ genes are only present in the $v a p A$ plasmid. This conservation of $v c g B$ in the $R$. equi pathogenicity islands, and within pathogenic mycobacterial species, suggests that this gene may play a role in the intracellular lifestyle of this group of pathogens important enough to resist corruption. This notion is strengthened by the observation that $v c g B$ is induced following phagocytosis and remains transcribed at least $48 \mathrm{~h}$ following phagocytosis, during which $R$. equi proliferates. Furthermore, the coordinated regulation of the $\mathrm{P}_{v c g A}$ and $\mathrm{P}_{v a p A}$ promoters supports a role for $v c g B$ in infection. However, an R. equi $v c g B$ mutant is not attenuated in a BALB/c mouse model (Ren \& Prescott, 2004), indicating that under these experimental conditions, $v c g B$ is not critical. The circumstances during the infection process that require $\mathrm{VcgB}$ therefore remain to be determined. Our current research aims to establish a function for $v c g B$ and other pathogenicity island genes, and to elucidate the signal transduction pathways governing their expression.

\section{ACKNOWLEDGEMENTS}

The authors thank Shinji Takai, Kitasato University, Towada, Japan, for making VapA monoclonal antibodies available. This work was supported by a grant from the Research Stimulus Fund of the Department of Agriculture, Fisheries and Food (RSF 06-379) and by a grant from Science Foundation Ireland (grant no. 02/IN.1/B203).

\section{REFERENCES}

Butcher, P. D., Mangan, J. A. \& Monahan, I. M. (1998). Intracellular gene expression. Analysis of RNA from mycobacteria in macrophages using RT-PCR. Methods Mol Biol 101, 285-306.

Buttner, M. J., Chater, K. F. \& Bibb, M. J. (1990). Cloning, disruption, and transcriptional analysis of three RNA polymerase sigma factor genes of Streptomyces coelicolor A3(2). J Bacteriol 172, 3367-3378.

Byrne, B. A., Prescott, J. F., Palmer, G. H., Takai, S., Nicholson, V. M., Alperin, D. C. \& Hines, S. A. (2001). Virulence plasmid of Rhodococcus equi contains inducible gene family encoding secreted proteins. Infect Immun 69, 650-656.

Byrne, G. A., Russell, D. A., Chen, X. \& Meijer, W. G. (2007). Transcriptional regulation of the virR operon of the intracellular pathogen Rhodococcus equi. J Bacteriol 189, 5082-5089.
Byrne, G. A., Boland, C. A., O'Connell, E. P. \& Meijer, W. G. (2008). Differential mRNA stability of the vapAICD operon of the facultative intracellular pathogen Rhodococcus equi. FEMS Microbiol Lett 280, 89-94.

Cole, S. T., Brosch, R., Parkhill, J., Garnier, T., Churcher, C., Harris, D., Gordon, S. V., Eiglmeier, K., Gas, S. \& other authors (1998). Deciphering the biology of Mycobacterium tuberculosis from the complete genome sequence. Nature 393, 537-544.

De La Peña-Moctezuma, A., Prescott, J. F. \& Goodfellow, M. (1996). Attempts to find phenotypic markers of the virulence plasmid of Rhodococcus equi. Can J Vet Res 60, 29-33.

Demangel, C., Stinear, T. P. \& Cole, S. T. (2009). Buruli ulcer: reductive evolution enhances pathogenicity of Mycobacterium ulcerans. Nat Rev Microbiol 7, 50-60.

Devulder, G., Pérouse de Montclos, M. \& Flandrois, J. P. (2005). A multigene approach to phylogenetic analysis using the genus Mycobacterium as a model. Int J Syst Evol Microbiol 55, 293-302.

Felsenstein, J. (1989). PHYLIP - phylogeny inference package (version 3.2). Cladistics 5, 164-166.

Fernandez-Mora, E., Polidori, M., Lührmann, A., Schaible, U. E. \& Haas, A. (2005). Maturation of Rhodococcus equi-containing vacuoles is arrested after completion of the early endosome stage. Traffic 6, 635-653.

Fleischmann, R. D., Alland, D., Eisen, J. A., Carpenter, L., White, O., Peterson, J., DeBoy, R., Dodson, R., Gwinn, M. \& other authors (2002). Whole-genome comparison of Mycobacterium tuberculosis clinical and laboratory strains. J Bacteriol 184, 5479-5490.

Giguère, S., Hondalus, M. K., Yager, J. A., Darrah, P., Mosser, D. M. \& Prescott, J. F. (1999). Role of the 85-kilobase plasmid and plasmidencoded virulence-associated protein A in intracellular survival and virulence of Rhodococcus equi. Infect Immun 67, 3548-3557.

Hondalus, M. K. \& Mosser, D. M. (1994). Survival and replication of Rhodococcus equi in macrophages. Infect Immun 62, 4167-4175.

Hondalus, M. K., Diamond, M. S., Rosenthal, L. A., Springer, T. A. \& Mosser, D. M. (1993). The intracellular bacterium Rhodococcus equi requires Mac-1 to bind to mammalian cells. Infect Immun 61, 2919-2929.

Hovel-Miner, G., Pampou, S., Faucher, S. P., Clarke, M., Morozova, I., Morozov, P., Russo, J. J., Shuman, H. A. \& Kalachikov, S. (2009). $\sigma^{\mathrm{S}}$ controls multiple pathways associated with intracellular multiplication of Legionella pneumophila. J Bacteriol 191, 2461-2473.

Hughes, K. L. \& Sulaiman, I. (1987). The ecology of Rhodococcus equi and physicochemical influences on growth. Vet Microbiol 14, 241-250.

Iriarte, M., Stainier, I. \& Cornelis, G. R. (1995). The rpoS gene from Yersinia enterocolitica and its influence on expression of virulence factors. Infect Immun 63, 1840-1847.

Jain, S., Bloom, B. R. \& Hondalus, M. K. (2003). Deletion of vapA encoding virulence associated protein $\mathrm{A}$ attenuates the intracellular actinomycete Rhodococcus equi. Mol Microbiol 50, 115-128.

Jones, D. T., Taylor, W. R. \& Thornton, J. M. (1992). The rapid generation of mutation data matrices from protein sequences. Comput Appl Biosci 8, 275-282.

Kang, J. G., Hahn, M. Y., Ishihama, A. \& Roe, J. H. (1997). Identification of sigma factors for growth phase-related promoter selectivity of RNA polymerases from Streptomyces coelicolor A3(2). Nucleic Acids Res 25, 2566-2573.

Kelly, B. G., Wall, D. M., Boland, C. A. \& Meijer, W. G. (2002). Isocitrate lyase of the facultative intracellular pathogen Rhodococcus equi. Microbiology 148, 793-798.

Klinkert, B. \& Narberhaus, F. (2009). Microbial thermosensors. Cell Mol Life Sci 66, 2661-2676. 
Larkin, M. A., Blackshields, G., Brown, N. P., Chenna, R., McGettigan, P. A., McWilliam, H., Valentin, F., Wallace, I. M., Wilm, A. \& other authors (2007). CLUSTAL_W and CLUSTAL_X version 2.0. Bioinformatics 23, 2947-2948.

Letek, M., Ocampo-Sosa, A. A., Sanders, M., Fogarty, U., Buckley, T., Leadon, D. P., González, P., Scortti, M., Meijer, W. G. \& other authors (2008). Evolution of the Rhodococcus equi vap pathogenicity island seen through comparison of host-associated vapA and $v a p B$ virulence plasmids. J Bacteriol 190, 5797-5805.

Letek, M., González, P., Macarthur, I., Rodríguez, H., Freeman, T. C., Valero-Rello, A., Blanco, M., Buckley, T., Cherevach, I. \& other authors (2010). The genome of a pathogenic Rhodococcus: cooptive virulence underpinned by key gene acquisitions. PLoS Genet 6, e1001145.

Li, L., Bannantine, J. P., Zhang, Q., Amonsin, A., May, B. J., Alt, D., Banerji, N., Kanjilal, S. \& Kapur, V. (2005). The complete genome sequence of Mycobacterium avium subspecies paratuberculosis. Proc Natl Acad Sci U S A 102, 12344-12349.

Lührmann, A., Mauder, N., Sydor, T., Fernandez-Mora, E., SchulzeLuehrmann, J., Takai, S. \& Haas, A. (2004). Necrotic death of Rhodococcus equi-infected macrophages is regulated by virulenceassociated plasmids. Infect Immun 72, 853-862.

Meijer, W. G. \& Prescott, J. F. (2004). Rhodococcus equi. Vet Res 35, 383-396.

Miranda-CasoLuengo, R., Duffy, P. S., O'Connell, E. P., Graham, B. J., Mangan, M. W., Prescott, J. F. \& Meijer, W. G. (2005). The ironregulated $i u p A B C$ operon is required for saprophytic growth of the intracellular pathogen Rhodococcus equi at low iron concentrations. J Bacteriol 187, 3438-3444.

Muscatello, G., Leadon, D. P., Klayt, M., Ocampo-Sosa, A., Lewis, D. A., Fogarty, U., Buckley, T., Gilkerson, J. R., Meijer, W. G. \& Vazquez-Boland, J. A. (2007). Rhodococcus equi infection in foals: the science of 'rattles'. Equine Vet J 39, 470-478.

Nielsen, A. T., Dolganov, N. A., Otto, G., Miller, M. C., Wu, C. Y. \& Schoolnik, G. K. (2006). RpoS controls the Vibrio cholerae mucosal escape response. PLoS Pathog 2, e109.

Ocampo-Sosa, A. A., Lewis, D. A., Navas, J., Quigley, F., Callejo, R., Scortti, M., Leadon, D. P., Fogarty, U. \& Vázquez-Boland, J. A. (2007). Molecular epidemiology of Rhodococcus equi based on $\operatorname{traA}$, vapA, and $v a p B$ virulence plasmid markers. J Infect Dis 196, 763-769.

Pfaffl, M. W. (2004). Quantification strategies in real-time PCR. In $A-Z$ of Quantitative PCR, pp. 87-112. Edited by S. A. Bustin. La Jolla, CA: International University Line.

Platt, T. (1986). Transcription termination and the regulation of gene expression. Annu Rev Biochem 55, 339-372.

Polidori, M. \& Haas, A. (2006). VapI, a new member of the Rhodococcus equi Vap family. Antonie van Leeuwenhoek 90, 299-304.

Ren, J. \& Prescott, J. F. (2003). Analysis of virulence plasmid gene expression of intra-macrophage and in vitro grown Rhodococcus equi ATCC 33701. Vet Microbiol 94, 167-182.
Ren, J. \& Prescott, J. F. (2004). The effect of mutation on Rhodococcus equi virulence plasmid gene expression and mouse virulence. Vet Microbiol 103, 219-230.

Ripoll, F., Pasek, S., Schenowitz, C., Dossat, C., Barbe, V., Rottman, M., Macheras, E., Heym, B., Herrmann, J. L. \& other authors (2009). Non mycobacterial virulence genes in the genome of the emerging pathogen Mycobacterium abscessus. PLoS ONE 4, e5660.

Rohde, K. H., Abramovitch, R. B. \& Russell, D. G. (2007). Mycobacterium tuberculosis invasion of macrophages: linking bacterial gene expression to environmental cues. Cell Host Microbe 2, 352-364.

Russell, D. A., Byrne, G. A., O’Connell, E. P., Boland, C. A. \& Meijer, W. G. (2004). The LysR-type transcriptional regulator VirR is required for expression of the virulence gene vapA of Rhodococcus equi ATCC 33701. J Bacteriol 186, 5576-5584.

Sambrook, J. \& Russell, D. W. (2001). Molecular Cloning: a Laboratory Manual. Cold Spring Harbor, NY: Cold Spring Harbor Laboratory.

Sekine, M., Tanikawa, S., Omata, S., Saito, M., Fujisawa, T., Tsukatani, N., Tajima, T., Sekigawa, T., Kosugi, H. \& other authors (2006). Sequence analysis of three plasmids harboured in Rhodococcus erythropolis strain PR4. Environ Microbiol 8, 334-346.

Stinear, T. P., Seemann, T., Pidot, S., Frigui, W., Reysset, G., Garnier, T., Meurice, G., Simon, D., Bouchier, C. \& other authors (2007). Reductive evolution and niche adaptation inferred from the genome of Mycobacterium ulcerans, the causative agent of Buruli ulcer. Genome Res 17, 192-200.

Stinear, T. P., Seemann, T., Harrison, P. F., Jenkin, G. A., Davies, J. K., Johnson, P. D., Abdellah, Z., Arrowsmith, C., Chillingworth, T. \& other authors (2008). Insights from the complete genome sequence of Mycobacterium marinum on the evolution of Mycobacterium tuberculosis. Genome Res 18, 729-741.

Takai, S., Fukunaga, N., Kamisawa, K., Imai, Y., Sasaki, Y. \& Tsubaki, S. (1996). Expression of virulence-associated antigens of Rhodococcus equi is regulated by temperature and $\mathrm{pH}$. Microbiol Immunol 40, 591594.

Takai, S., Hines, S. A., Sekizaki, T., Nicholson, V. M., Alperin, D. A., Osaki, M., Takamatsu, D., Nakamura, M., Suzuki, K. \& other authors (2000). DNA sequence and comparison of virulence plasmids from Rhodococcus equi ATCC 33701 and 103. Infect Immun 68, 6840-6847.

Toyooka, K., Takai, S. \& Kirikae, T. (2005). Rhodococcus equi can survive a phagolysosomal environment in macrophages by suppressing acidification of the phagolysosome. J Med Microbiol 54, 10071015.

von Bargen, K., Wohlmann, J., Taylor, G. A., Utermöhlen, O. \& Haas, A. (2011). Nitric oxide-mediated intracellular growth restriction of pathogenic Rhodococcus equi can be prevented by iron. Infect Immun 79, 2098-2111.

Edited by: G. R. Stewart 